DOI https://doi.org/10.30525/978-9934-588-80-8-1.4

\title{
СОЦІАЛЬНІ МЕРЕЖІ ТА ЖИТТЕВИЙ СВІТ ОСОБИСТОСТІ: ПСИХОЛОГІЧНА І СОЦІАЛЬНА ПРОБЛЕМАТИКА
}

\author{
Ганущак P. I. \\ аспірант кафедри психологіі \\ Львівський національний університет імені Івана Франка \\ м. Львів, Украӥна
}

Життєвий світ особистості - це не лише безпосереднє буття людини, але й іï внутрішня психологічна система цінностей, переконань та інтерпретацій, яка формується шляхом постійного взаємовпливу внутрішнього і зовнішнього світів одне на одного. В результаті власне життєвий світ визначає ставлення людини до зовнішнього (фізичного) світу, до інших людей (соціального світу) і до самої себе та проявляється у іiі поведінці. Зрозуміло, що у формуванні життєвого світу визначальну роль відіграє соціальне та культурне середовище. А у наш час додався ще один потужний фактор - середовище технологічне. Метою дослідження $\epsilon$ проаналізувати вплив таких новітніх технологій як Інтернет та соціальні мережі на життєвий світ особистості.

На нашу думку, життєвий світ сучасної людини неможливо вивчати поза контекстом епохи інформаційних технологій. Інформаційна ера це сучасний період в історії людства, що характеризується переходом до цифрової, комп'ютеризованої індустрії, основаної на трансфері інформації. Основні іiі рушійні сили - масове поширення обчислювальної техніки, перш за все - персональних комп'ютерів, всеосяжне проникнення Інтернету, масове застосування портативних комунікаційних пристроїв, популяризація соціальних мереж та різноманітних мобільних додатків тощо, що кардинально змінило способи людських комунікацій та взаємодій. До прикладу, кількість користувачів соціальної мережі Facebook на липень 2020 року сягнула 2,7 мільярда активних користувачів, а мобільний додаток мережі $\epsilon$ найбільш завантажуваним додатком останнього десятиліття. У порівнянні з 2015 роком кількість користувачів збільшилася у 1,8 рази і продовжує рости (зараз у соцмережі щохвилини реєструються 400 нових учасників).

Важко заперечувати, що соціальні мережі можуть певним чином впливати на різні аспекти життєвого світу особистості, позначаючись в результаті і на іï поведінці у світі реальному. Можна, до прикладу, 
згадати роль соціальних медіа у хвилях протестів та революцій в різних країнах, де вони виступили не лише як засіб організації та інформування мас, але й як інструмент формування громадської думки. Отже, дослідження взаємозв'язків та взаємовпливів між життєвим світом людей та характером їх активності у соціальних мережах видаються вкрай важливими. Далі ми на прикладі кількох досліджень розглянемо деякі з таких впливів на варіанти прояву життєвого світу особистості, зокрема, на іiі актуальну поведінку, емоційну сферу, переконання, сприйняття реальності тощо.

Дослідження групи вчених 3 Каліфорнійського університету продемонструвало, як за допомогою соцмереж можна маніпулювати політичною активністю громадян та виявом політичних переконань у реальному житті. Вчені використали соціальну мережу Facebook як інструмент, аби поекспериментувати із явкою на вибори до конгресу США у 2010 році. У стрічці новин користувачів з'явилося повідомлення із закликом сходити проголосувати та опустити бюлетень до урни. Одній частині з них, на відміну від іншої, додатково показали юзерпіки шістьох друзів, які нібито вже проголосували (так зване «соціальне повідомлення»), що й стало вирішальним. Дослідники порахували, що їм вдалося мобілізувати на вибори до конгресу зайві 340 тисяч чоловік [2]. Таким чином, проста маніпуляція повідомленням про вибори у соціальній мережі виявилася вкрай ефективною для впливу на бажання людей висловити свої політичні уподобання безпосередньо на виборчій дільниці. Ми вважаємо, що це становить певну загрозу не лише для кожного окремого користувача, але й для суспільства в цілому, адже соцмережі можуть використовуватися для не зовсім чесних політичних махінацій думками і намірами людей.

Інше дослідження, проведене у 2012 році співробітниками Facebook, показує, що за допомогою соціальних мереж можна впливати і на емоційну сферу людини. Дослідники піддали вибірковій цензурі френдстрічку користувачів без їхнього відома таким чином, що одна частина користувачів переставала бачити у себе в стрічці до $90 \%$ записів з «негативним» змістом, інша - до 90\% «позитивних» записів. «Негатив» від «позитиву» відрізняла спеціальна програма-фільтр за ключовими словами-маркерами, які певним чином співвідносяться 3 позитивними і негативними емоціями. Команду Facebook цікавило, як зачистка стрічки відіб'ється на активності користувачів соцмережі. Виявилося, що ті, у кого зі стрічки повидаляли «позитивні» записи, самі почали писати більш похмурі тексти: частота відповідних слівмаркерів зросла настільки, що з ймовірністю 99,3\% це не можна було назвати випадковим збігом. Автори дослідження пишуть про «масове 20 
зараження емоціями через соцмережі» та стверджують, що, всупереч колишнім припущенням, взаємодія обличчям до обличчя і невербальні сигнали не є конче необхідними для зараження емоціями [3]. Отож, як бачимо, сплановане маніпулювання змістом стрічки новин у соціальній мережі здатне викликати у користувачів емоції з певним знаком, що, на нашу думку, теж потенційно може бути використане 3 різними сумнівними та неетичними цілями.

Загалом, алгоритми соцмереж та пошукових систем в будь-якому випадку працюють як свого роду криве дзеркало, що викривляє реальність. До прикладу, Facebook й так постійно приховує від користувачів $80 \%$ всього написаного їхніми друзями. Алгоритм, знаючи інтереси і вподобання користувача, вибирає лише незначну частину, все інше буде забраковано. A Google завжди підлаштовує пошукову видачу за одним і тим же запитом під інтереси конкретного користувача. Це становить певну проблему, адже таким чином соцмережі та пошукові системи активно допомагають нам ізолювати себе від несхожих думок, що створює ілюзію, начебто наші погляди та переконання поділяє абсолютна більшість людей. Небезпечним для відкритих публічних дискусій є те, що це стосується в тому числі й проблемних та суспільно значущих тем: генетично модифіковані організми, екстракорпоральне запліднення, аборти, вакцинація, здоровий спосіб життя, «легалайз», екологічні проблеми, сексуальна орієнтація, сексуальна просвіта тощо. Пошуковики на наш запит просто видаватимуть сайти, інформація на яких лише підтверджуватиме наші переконання, та приховуватимуть ресурси із даними, які їм суперечать.

Механізм фільтрів Facebook можна запідозрити навіть у політичній цензурі. До прикладу, він обмежує доступ до новин, які йдуть врозріз з політичними переконаннями аудиторії. Facebook жорстко проріджує стрічку новин, намагаючись за попередніми вподобаннями передбачити, що з нового контенту зацікавить певного користувача, а що ні. На цій стадії і відбувається мимовільна політична цензура, адже користувачі частіше лайкають те, що добре узгоджується з їхніми переконаннями. Тому Facebook намагається видати їм якомога менше нецікавого - і частка «конфліктних» новин падає.

Експерти 3 дослідницького відділу Facebook i Мічиганського університету вказують, що природне бажання читати однодумців i небажання лайкати те, що розходиться 3 усталеними поглядами, породжує парадокс: якщо надати користувачам повну свободу доступу до інформації - вони самі докладуть зусиль, аби себе дезінформувати [1].

Ще однією проблемою $\epsilon$ те, що соцмережі створюють надміру яскраве враження про чуже життя. Люди зазвичай пишуть про рідкісне 
і приємне - подорожі, подарунки, народження дітей і святкові події, а не про робочу рутину чи проблеми. В результаті починає здаватися, що життя - це постійне свято, яке проходить повз нас.

Одним 3 наслідків такого викривлення реальності, зокрема, сприйняття друзів у соцмережах як більш успішних, $\epsilon$ те, що у багатьох людей виникають негативні наслідки, як от страх i тривога, які $\epsilon$ частиною нової, нещодавно окресленої психологічної проблеми - так званого синдрому втрачених можливостей, FOMO (fear of missing out). Для синдрому втрачених можливостей характерні високий рівень напруженості, тривожності та відчуття меншовартості від того, що людина нібито пропускає якісь можливості, а також нав'язливий страх прогавити якусь важливу інформацію чи цікаву подію, поки вона перебувала офлайн [4]. Сучасна людина живе під великим тиском соціальних мереж, де чуже життя видається більш яскравим та насиченим, аніж іiї власне.

Отож, як бачимо, впливи соціальних мереж на життєвий світ сучасної людини несуть певні небезпеки та ставлять перед людиною серйозні виклики - як сформувати та зберегти цілісний, несуперечливий та гармонійний життєвий світ, який би максимально органічно та несуперечливо співвідносився із реальністю. Враховуючи той факт, що в сучасному світі соціальні мережі стають невід'ємним елементом буття людини, слід виняткової уваги надавати особливостям взаємодії та взаємовпливу між реальним та віртуальним, зокрема і 3 метою запобігання негативним і небажаним ефектам, які можуть становити певну загрозу для цілісності та гармонійності життєвого світу особистості.

\section{Література:}

1. Bakshy E., Messing S. and Adamic L. A. Exposure to ideologically diverse news and opinion on Facebook. Science. 2015. Vol. 348, № 6239. P. 1130-1132.

2. Bond R. M., Fariss Ch. J., Jones J. J., Kramer A., Marlow C., Settle J. E. and Fowler J. H. A 61-million-person experiment in social influence and political mobilization. Nature. 2012. Vol. 489, № 7415. P. 295-298.

3. Kramer A., Guillory J. E. and Hancock J. T. Experimental evidence of massive-scale emotional contagion through social networks. Proceedings of the National Academy of Sciences. 2014. Vol. 111, № 24. P. 8788-8790.

4. Przybylski A., Murayama K., DeHaan C., Gladwell V. Motivational, emotional, and behavioral correlates of fear of missing out. Computers in Human Behavior. 2013. Vol. 29, № 4. P. 1841-1848. 